\title{
The effect of experimental variation in the quantity of pancreatic secretion on the digestion and utilization of milk-substitute diets by the calf
}

\author{
By J. H. TERNOUTH*, J. H. B. ROY, I. J. F. STOBO, P. GANDERTON, \\ CATHERINE M. GILLIES AND SUSAN M. SHOTTON \\ National Institute for Research in Dairying, Shinfield, Reading $R G 2{ }_{9} A T$
}

(Received 30 April 1973 - Accepted 5 fuly 1973)

\begin{abstract}
r. Apparent digestibility, apparent absorption and nutrient-balance studies were made with two Ayrshire and three Friesian calves given milk-substitute diets. Cannulas were inserted into the duodenum of the calves at about $2 \mathrm{I} \mathrm{d}$ old, so that the quantity of pancreatic secretion entering the duodenum could be varied.

2. After cannulation, there was a significant reduction in the apparent digestibility of the dry matter, organic matter, crude protein and fat, and in the apparent absorption of calcium and phosphorus from a milk-substitute diet containing 'mildly' pre-heated, spray-dried skimmilk powder. The amounts of nitrogen and $P$ retained by the calves were also significantly reduced.

3. Collection and removal of the pancreatic secretion for a period of $12 \mathrm{~h} / \mathrm{d}$ resulted in a further significant reduction in the apparent digestibility of the dry matter, organic matter and crude protein of the milk-substitute diet.

4. At $77 \mathrm{~d}$ of age, there was no significant effect on the nutrient balance or on the digestibility of a diet containing a 'severely' pre-heated, spray-dried skim-milk powder when the normal secretion of the pancreas was supplemented for $I 2 \mathrm{~h} / \mathrm{d}$ with additional pancreatic secretion collected from the same calf.

5. Friesian calves, in comparison with Ayrshires, tended to have a higher digestibility of dry matter, organic matter and fat, apparent absorption of $\mathrm{Ca}$ and $\mathbf{P}$ and retention of $\mathrm{N}, \mathrm{Ca}$ and $P$. These differences were apparent both before and after the calves were cannulated.
\end{abstract}

It has been found that the quantities and pattern of secretion of pancreatic proteolytic enzymes vary considerably when calves are given different milk diets (Ternouth \& Buttle, 1973; Ternouth, Roy \& Siddons, 1974). However, these experiments did not indicate whether the changes in enzyme secretion affected the processes of digestion. Although the quantities of pancreatic proteases secreted by calves whose diet contained 'severely' pre-heated, spray-dried skim-milk powder were much lower than those from calves given 'mildly' pre-heated, spray-dried skim-milk powder, the experiment (Ternouth et al. 1974) was not designed to investigate the reason for the low digestibilities of dry matter and protein of the 'severely' pre-heated milk reported by Shillam \& Roy ( 1963$)$.

We studied the role of the pancreatic enzymes in the digestion of milk diets. Calves were cannulated so that the quantity of pancreatic secretion entering the duodenum could be altered and the effect on digestibility and nutrient retention examined.

Other experiments on the role of pancreatic enzymes, in the pig, involved ligation of the pancreatic duct, which resulted in atrophy of the exocrine structures of the

* Present address: Department of Animal Husbandry, University of Queensland, St Lucia, Queensland 4067, Australia. 
Table r. Age, mean weight of calves and their diets in each of the seven digestibility and nutrient-balance periods

\begin{tabular}{|c|c|c|c|c|}
\hline & & Tean values for five calve & & \\
\hline $\begin{array}{l}\text { Experimental } \\
\text { period }\end{array}$ & Diet & $\begin{array}{l}\text { Variation in quantity } \\
\text { of pancreatic secretion } \\
\text { entering duodenum }\end{array}$ & $\begin{array}{l}\text { Time after } \\
\text { surgery (d) }\end{array}$ & $\begin{array}{l}\mathrm{W}^{0 \cdot 75} \\
(\mathrm{~kg})\end{array}$ \\
\hline I & M & None & Before* & $16 \cdot 7$ \\
\hline 2 & $\mathrm{M}$ & None & II & I9 \\
\hline 3 & $\mathrm{M}$ & Decreased & 21 & 20 \\
\hline 4 & M & None & 32 & 2177 \\
\hline 5 & $\mathbf{S}$ & None & 44 & \\
\hline 6 & $\mathbf{S}$ & Increased & 56 & 24 \\
\hline 7 & $\mathbf{s}$ & None & 68 & 25.7 \\
\hline
\end{tabular}

M, diet containing 'mildly' pre-heated, spray-dried skim-milk powder; $\mathrm{S}$, diet containing 'severely' pre-heated, spray-dried skim-milk powder.

* The calves were cannulated at a mean age of $21 \mathrm{~d}$.

gland (Pekas, Hays \& Thompson, 1964; Anderson \& Ash, 1971). In those experiments there may have been gastric and intestinal physiological adaptation to the lack of pancreatic enzymes in the post-surgical recovery period, which may explain the relatively small effect on digestion. Our experiment was designed to measure the effects of surgical cannulation separately from those of diversion of the pancreatic enzymes from the duodenum.

Taylor (1962) found that, when pancreatic enzymes were prevented from entering the duodenum, the quantity of enzymes secreted decreased. In our experiment, the quantity of pancreatic secretion entering the duodenum was changed for a period of $12 \mathrm{~h} / \mathrm{d}$ to minimize changes in the rate of synthesis and secretion of the enzymes.

\section{EXPERI MENT AL}

Animals and diets. Two Ayrshire (calf nos. $\mathrm{r}$ and 2) and three Friesian bull calves (calf nos. 3, 4 and 5) were used in the experiment. The calves were reared in individual pens with expanded-metal floors (Roy, Stobo, Gaston \& Greatorex, 1970). After completion of the first digestibility and nutrient-balance trial, each calf was cannulated using a double cannulation technique (Ternouth \& Buttle, 1973). This involved placing a T-type cannula in the duodenum, caudal to the opening of the bile duct, and a second T-type cannula in a pancreato-duodenal sac from which the pancreatic secretion was collected. Calf nos. I- 5 were cannulated at $15,27,19,14$ and $28 \mathrm{~d}$ of age respectively. After surgery, each calf was subjected to a further six digestibility and nutrient-balance trials. The plan of the experiment is shown in Table $r$. The milks were reconstituted from one of two skim-milk powders mixed with ultra-high-fat milk powder $(700 \mathrm{~g} / \mathrm{kg})$ to give a final concentration $(\mathrm{g} / \mathrm{l})$ of 24 fat and 120 dry matter. The spray-dried skim-milk powders were either 'mildly' pre-heated (M) or 'severely' pre-heated (S) during processing; non-casein N:total N ratios were 0.194 and 0.103 respectively. The fat constituents of the ultra-high-fat milk powder, which also contained a vitamin and mineral supplement (Roy, Stobo \& Gaston, 1968; Roy, 
Stobo, Gaston, Shotton \& Ganderton, I973) were (g fat $/ \mathrm{kg}$ ) 280 coconut oil, 660 beef tallow and 60 lecithin.

Experimental procedures. The calves were weighed weekly and also on 3 successive days before the beginning of each digestibility and nutrient-balance period, the quantity of milk offered being adjusted to a daily rate of $5^{\circ} \mathrm{g}$ dry-matter $/ \mathrm{kg}$ live weight ${ }^{0.75}$. The calves were fed by bucket twice daily at 09.00 and 21.00 hours. Milk was refused by calf 3 during digestibility period 3 .

Each digestibility and nutrient-balance period lasted $5 \mathrm{~d}$. Digestibility and $\mathrm{N}$, phosphorus and calcium balance trials were done using the techniques described by Roy, Stobo, Gaston \& Greatorex (1970). During period 3, the pancreatic secretion of each calf was collected between 09.00 and 21.00 hours for $7 \mathrm{~d}$, beginning $2 \mathrm{~d}$ before the start of the digestibility and nutrient-balance period. The pancreatic secretion was collected in a plastic bottle attached to the harness of the calf. The collection bottle was emptied every $\mathrm{I}$ or $2 \mathrm{~h}$. The volume of pancreatic secretion was recorded and a similar volume of a buffered electrolyte solution was returned to the duodenum immediately. The electrolyte solution contained $(\mathrm{g} / \mathrm{l}): 5.85 \mathrm{NaCl}, 4 \cdot 20 \mathrm{NaHCO}_{3}$ and $0.37 \mathrm{KCl}$. The mean volume of pancreatic secretion collected was $508 \mathrm{ml} / \mathrm{r} 2 \mathrm{~h}$. The pancreatic secretions were stored at $-25^{\circ}$. During period 6 , the pancreatic secretion of each calf was collected and measured by the technique used in period 3 , but the fluid secreted was returned to the calf together with the pancreatic secretion collected from the same calf for the same period of time in period 3 . The mean volume of pancreatic secretion collected during period 6 was $45^{2} \mathrm{ml} / \mathrm{r} 2 \mathrm{~h}$. The mean volume of pancreatic secretion returned to each calf during period 6 was therefore $960 \mathrm{ml} / \mathbf{1 2} \mathrm{h}$.

Analytical methods. Faeces were dried to constant weight at $100^{\circ}$ for dry-matter estimation. The fat content of the faeces was determined by a modification of the Werner-Schmid method (Davis \& MacDonald, I953) and ash content was determined by incineration in an electric muffle furnace at a temperature not exceeding $550^{\circ}$. Ca content of the faeces was determined by atomic absorption spectroscopy on a sample prepared by a dry-ashing technique, and inorganic $\mathrm{P}$ in both faeces and urine was determined by the method of Cavell (1955). N was determined in urine and acidified faeces by the Kjeldahl method.

Statistical analysis. The sequence of treatments used, which was similar for all calves, was not suitable for comparison of the two milk diets and not ideal for studying the effects of surgery or variation of pancreatic secretion, but was necessitated by the small number of calves available and the fear that undesirable side effects such as diarrhoea would have occurred if some calves had received diet $\mathrm{S}$ before and after surgery.

Missing values were calculated (Yates, 1933) for calf 3 in period 3 and for calf 5 in period 7 before the results were statistically analysed. The missing values were fitted because calf 3 refused some milk during period 3 and because a loss of pancreatic secretion resulting from leakage around the pancreatic cannula was observed with calf 5 during period 7 . 

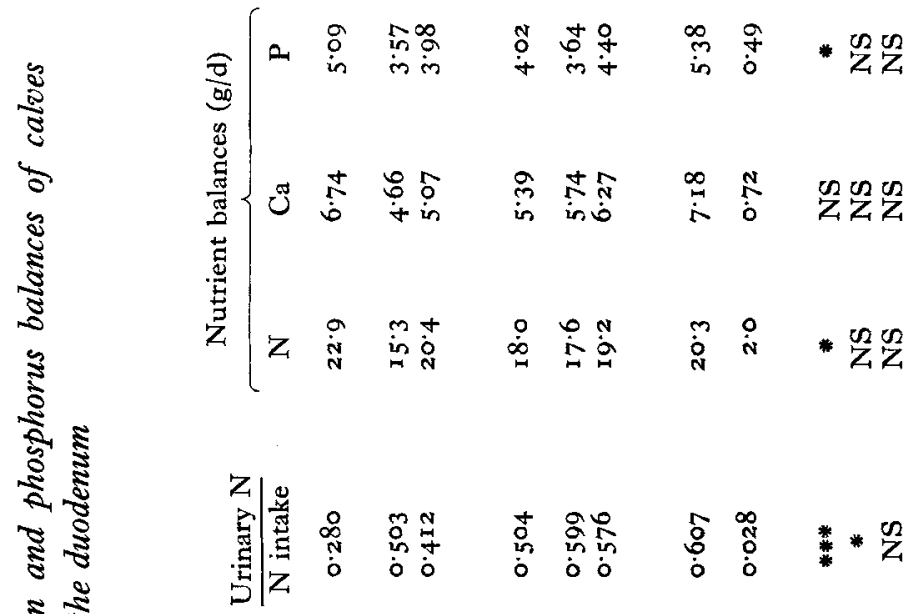

졸

芩

8

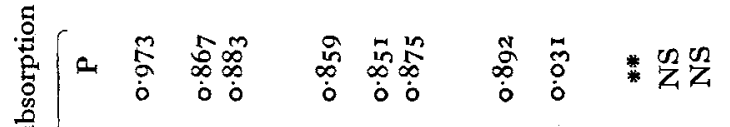

.

ป

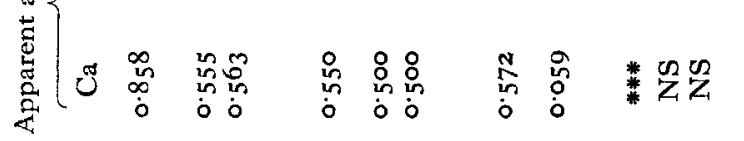

ए

ร.

雪

(2)

?

20

ป

莡

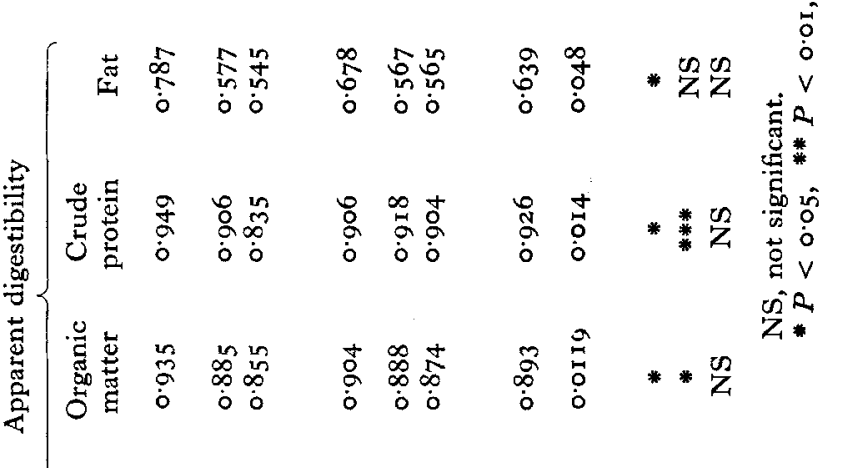

;

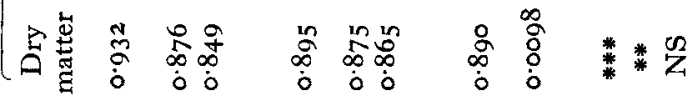

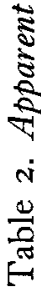

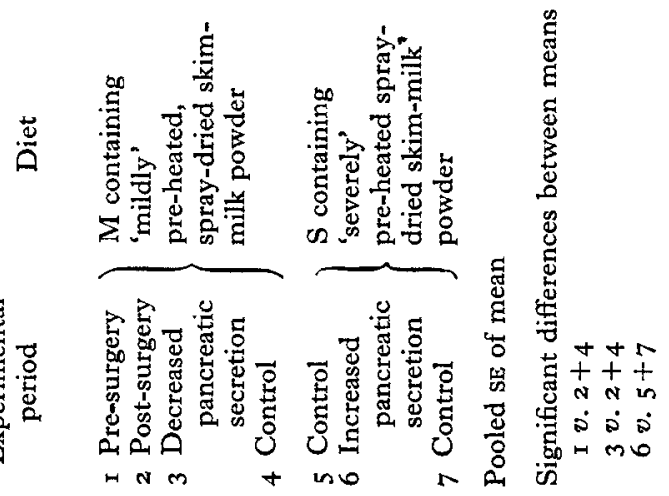


Table 3. Apparent digestibility and absorption of milk-substitute diets and nutrient balances of Ayrshire and Friesian calves given the diets

\begin{tabular}{|c|c|c|c|}
\hline \multicolumn{4}{|c|}{ (Mean for all seven experimental periods) } \\
\hline & \multicolumn{2}{|c|}{ Breed } & \multirow{2}{*}{$\begin{array}{c}\text { SE of the } \\
\text { difference } \\
\text { between breeds }\end{array}$} \\
\hline & Ayrshire & Friesian & \\
\hline \multicolumn{4}{|l|}{ Apparent digestibility: } \\
\hline Dry matter & $0.85 \mathrm{r}$ & 0.905 & 0.052 \\
\hline Organic matter & 0.863 & 0.910 & 0.046 \\
\hline Crude protein & 0.902 & 0.909 & 0.072 \\
\hline Fat & 0.520 & 0.691 & 0.153 \\
\hline \multicolumn{4}{|l|}{ Apparent absorption: } \\
\hline Calcium & 0.419 & 0.696 & 0.295 \\
\hline Phosphorus & 0.845 & 0.913 & 0.171 \\
\hline \multicolumn{4}{|l|}{ Balance: } \\
\hline Nitrogen $(g / d)$ & I 5.8 & $2 I \cdot 3$ & $\mathrm{II} \cdot 6 \mathrm{I}$ \\
\hline Nitrogen $\left(g / W^{0 \cdot 75}\right.$ per $\left.d\right)$ & 0.78 & 0.98 & 0.44 \\
\hline Calcium $(g / d)$ & 3.98 & $7 \cdot 10$ & $3 \cdot 38$ \\
\hline Calcium $\left(g / W^{0.75}\right.$ per $\left.d\right)$ & 0.196 & 0.323 & 0.13 \\
\hline Phosphorus (g/d) & 3.09 & 2.10 & $2 \cdot 03$ \\
\hline Phosphorus (g/W0.75 per $\mathrm{d}$ ) & 0.159 & 0.235 & 0.21 \\
\hline
\end{tabular}

\section{RESULTS}

Nine calves were cannulated after completing the first experimental period, but the results are those from the five which recovered satisfactorily from surgery. The reasons for the failure of the other calves are discussed elsewhere (Ternouth \& Buttle, I973). Between the start of the first (pre-surgery) and final ( $7^{\text {th }}$ ) experimental periods, the calves gained $33 \cdot 2 \mathrm{~kg}(0 \cdot 45 \mathrm{~kg} / \mathrm{d})$.

Digestibility and nutrient-balance results are shown in Table 2. Comparison of the results before and after surgery (period $\mathrm{I} v .2+4$ ) indicated that the cannulation of the calves significantly reduced the digestibility and absorption of all the fractions measured, particularly fat and $\mathrm{Ca}$. Urinary $\mathrm{N}$ losses also increased significantly. $\mathrm{Ca}, \mathrm{N}$ and $\mathrm{P}$ retention were reduced, although the change in $\mathrm{Ca}$ retention was not significant.

After surgery, there was a slight but not significant increase in the digestibility and nutrient balance of the calves; this increase was observed between periods 2 and 4 , and also periods 5 and 7 (i.e. between control periods on both diet $M$ and S).

When the quantity of pancreatic enzymes entering the duodenum was reduced in period 3, there were significant reductions in the apparent digestibility of dry matter and organic matter of diet M. Although the apparent digestibility of crude protein was also significantly reduced (period $3 v .2+4 ; P<0.001$ ), the size of the reduction was only $8 \%$, and $\mathrm{N}$ retention tended to be improved due to the decreased loss of urinary N. Fat digestibility was not significantly reduced during period 3 , although the mean value was the lowest recorded.

When the pancreatic secretions were returned to the calves, there was no significant effect on the digestibility or nutrient balance of diet $\mathrm{S}$.

Table 3 shows the results for the Ayrshire and Friesian breeds. Although the quantity of milk given was based on metabolic body size, there was a tendency for the 
Friesians to have higher digestibilities of all nutrients, except for crude protein, and to have greater $\mathrm{N}, \mathrm{Ca}$ and $\mathrm{P}$ balances.

\section{DISCUSSION}

Cannulation caused a significant reduction in the digestibility of the diet. During period I, the digestibility of all nutrients of diet M (except fat) compared favourably with values obtained from other similar diets (Roy, Stobo, Gaston \& Greatorex, 1970). The low mean digestibility of the fat was a reflection of the poor digestibility shown by the two Ayrshire calves (0.612 and 0.657 respectively). After surgery, increases in digestibility and nutrient balance of the calves may have been associated with either a long post-surgical recovery period or normal physiological changes relating to increasing age in the young calf, or both.

It is not clear whether the reduction in digestibility was associated with the specific surgical procedure used here. Harris \& Phillipson (1962) and D. A. Corse (personal communication) found no consistent changes in the digestibility of organic matter, $\mathrm{N}$ or ash when duodenal and ileal re-entrant cannulas were placed in adult sheep. However, Harris \& Phillipson ( 1962) and Bruce, Goodall, Kay, Phillipson \& Vowles (r966) both reported considerable reductions $(7.8$ and $5.0 \mathrm{~kg}$ respectively) in the live weight of sheep after cannulation. Similar weight reduction after surgery was not observed in this experiment (see Table r).

From our results, it is apparent that pancreatic lipase and proteases are important enzymes in the milk-fed calf. Ternouth \& Buttle (1973) found that incubation of pancreat-duodenal pouch secretions for $30 \mathrm{~min}$ at $39^{\circ}$ resulted in $80 \%$ loss of lipase activity but only $20 \%$ loss of protease activity. Siewert \& Otterby (I 968 ) reported that salivary pregastric esterase has a high specificity for triglycerides containing butyric acid, but lower specificity for triglycerides whose fatty acids have twelve or more carbon atoms. Unpublished observations of J. D. Edwards-Webb and S. Y. Thompson have shown that, when a diet containing a fat with long-chain fatty acids in proportions similar to those used in our experiment is offered through a teat, free fatty acids derived from dietary triglycerides are present in the duodenal effluent in considerable amounts. Therefore, significant hydrolysis, even of long-chain fatty acids, occurs before the point of entry of the pancreatic enzymes. The fat in our diets was mainly tallow, and mainly contained triglycerides of long-chain fatty acids (Toullec, 1967), thus indicating quantitatively that pancreatic lipase could be an important triglyceridase. Our results indicate that the activity of the pancreatic lipase is severely reduced during its passage through the pancreato-duodenal sac, the cannulas and the external connecting U-tube, and that pancreatic lipase is important in the hydrolysis in the intestine of triglycerides containing long-chain fatty acids.

In period 3 , the pancreatic secretion of the calves was removed for $12 \mathrm{~h}$ each day and it was assumed that the quantity of pancreatic enzymes entering the duodenum was reduced by $50 \%$. The time from removal of pancreatic enzymes from the calves to the loss of their hydrolytic activity in the small intestine has not been established. If a significant proportion of the enzymes was absorbed onto the mucosal membrane 
of the small intestine (Ugolev, r 965; Goldberg, Campbell \& Roy, 1969), they may be active for a longer period, and the effective enzyme loss after removal of pancreatic secretion may be reduced. Adsorbed enzymes may be less readily inactivated than those which are free in the lumen of the intestine, as they are in a micro-environment which probably has a higher $\mathrm{pH}$. Also, the enzymes are spatially fixed and are therefore less likely to be digested, especially by trypsin (Khayat \& Christophe, 1969).

When pancreatic enzymes were diverted from the duodenum in period 3 , there was a significant decrease in the digestibility of the dry-matter, organic-matter and crudeprotein fractions of the diet. These reductions are similar to those found in young milk-fed pigs (Pekas et al. 1964) and in older pigs given dry diets (Anderson \& Ash, 1971). There was no significant reduction in fat digestibility, which could indicate that there was little additional loss of pancreatic lipase activity from the duodenum when the pancreatic secretion was diverted in period 3 . In rats (Karvinen, Lin \& Ivy, I957 $a, b$ ) and in pigs (Pekas et al. 1964; Anderson \& Ash, 1971) the absorption and apparent digestibility of fats are reduced when the pancreatic duct is ligated. The reduced absorption of $\mathrm{Ca}$ after surgery might reflect the reduced digestibility of fat resulting from the formation of $\mathrm{Ca}$ soaps of the fatty acids. It is well known that in malabsorption syndromes, poor lipid absorption is associated with an increase in faecal Ca excretion (Givens, 1917 ).

In this experiment $66 \%$ of the dietary fat was in the form of tallow and, of the fatty acids, $56 \%$ were palmitic and stearic acids (Roy et al. 1973), which are known to have a low digestibility in the rat (Carroll \& Richards, 1958) and in the intact calf (Toullec \& Mathieu, 1969; Raven, 1970) and this may be associated with their ability to form insoluble soaps.

There was a significant relationship between the intestinal absorption of $\mathrm{Ca}$ and the digestibility of the fat. As $\mathrm{Ca}$ absorption ranged from 0.12 to 0.96 and fat digestibility from 0.40 to 0.95 , a regression was calculated for all thirty-three collection periods; the regression was:

$$
y=0.308+0.538 x \quad \text { (Residual SD 0.090, SE of slope } 0.067, \mathrm{df} .3 \mathrm{I} \text { ). }
$$

where $y$ is digestibility of fat and $x$ is absorption of calcium.

It was deduced from this equation that when absorption of $\mathrm{Ca}$ was completely impaired only $30.8 \%$ of the fat was digested. This value is similar to the proportion of fatty acids with less than sixteen carbon atoms + the polyunsaturated fats in the diet $(29 \%)$, all of which are known to have a high digestibility in the calf (Toullec \& Mathieu, I969). It has also been shown in the rat that the amount of serum lipids decreases and that of faecal lipids increases when tallow is the source of dietary fat and dietary $\mathrm{Ca}$ intake is increased (Fleischman, Yacowitz, Hayton \& Bierenbaum, r966). However, milk substitutes with a Ca content similar to that used in this experiment have produced fat digestibilities of up to 0.96 in intact calves (Roy, Stobo, Gaston \& Greatorex, 1970): therefore the low $\mathrm{Ca}$ absorption apparently resulted from impaired fat digestion rather than the reverse.

The impaired digestion of dietary fat in these experiments may also have been associated with a shortage of monoglyceride or lysolecithin for adequate micelle 
formation. Micelle formation within the intestinal lumen occurs when liquid fattyacid chains are surrounded by a sheath of amphipathically-orientated, monoglyceride-bile salt or lysolecithin-bile salt molecules. The former appear to be important in the simple-stomached animal (Desnuelle, 1968) while the latter are important in the ruminant animal (Bath \& Hill, I967; Leat $\&$ Harrison, 1969), although recently Harrison \& Leat (1972) suggested that lysolecithin produced by the action of pancreatic lipase on biliary lecithin is required by non-ruminant animals. The addition of lecithin to homogenized fat results in an increase in the digestibility of tallow, but has little or no effect on the digestibility of fat or on the performance of calves given milk substitutes containing a fat of high inherent digestibility (Roy, Shillam, Thompson \& Dawson, r96r; Raven \& Robinson, I964a,b; Raven, I970).

The digestibility of diet $\mathrm{S}$ appeared to be similar to that of diet M. This experiment was not designed to compare diets M and S, but Shillam \& Roy ( 1963$)$ found that 'severe' heat-denaturation of the whey proteins resulted in a significant depression of dry-matter and $\mathrm{N}$ digestibilities during the first 3 weeks of life. However, in this experiment diet $S$ was not offered to the calves until they were 9 weeks old. As the digestibility of diet $\mathrm{S}$ was high, little improvement could be expected when additional pancreatic enzymes were returned to the duodenum of the calf.

Non-significant differences between breeds were observed in the digestibility and $\mathrm{N}, \mathrm{Ca}$ and $\mathrm{P}$ balances of calves given the milk diets. When assessing these results it must be noted that only five calves were involved and the calves were cannulated after the first trial period. With the exception of $\mathrm{N}$ digestibility, these breed differences are similar to those reported by Roy $(1967,1970)$ and by Roy, Stobo \& Gaston (1970). The poor fat digestion both before and after cannulation was particularly marked in the Ayrshire calves.

Although the pancreatic proteolytic enzymes have been shown to be important in digestion in the milk-fed calf, the quantitative significance of these enzymes has not been determined successfully.

The authors thank MrE. Florence for his help with the chemical analyses. J. H. T. gratefully acknowledges the financial support of the Australian Dairy Produce Board.

\section{REFERENCES}

Anderson, D. M. \& Ash, R. W. (1971). Proc. Nutr. Soc. 3o, 34 A.

Bath, I. H. \& Hill, K. J. (I967). F. agric. Sci., Camb. 68, I39.

Bruce, J., Goodall, E. D., Kay, R. N. B., Phillipson, A. T. \& Vowles, L. E. (1966). Proc. R. Soc. B I66, 46 .

Carroll, K. K. \& Richards, J. F. (1958). F. Nutr. 64, 4 I I.

Cavell, A. J. (1955). F. Sci. Fd Agric. 6, 479.

Davis, J. G. \& MacDonald, F. J. (1953). Richmond's Dairy Chemistry 5th ed. London: Charles Griffin.

Desnuelle, P. (1968). In Handbook of Physiology Section 6. Alimentary Canal Vol. 5, p. 2629 [C. F. Code, editor]. Washington, DC: American Physiological Society.

Fleischman, A. I., Yacowitz, H., Hayton, T. \& Bierenbaum, M. L. (I966). F. Nutr. 88, 255.

Givens, M. H. (1917). Y. biol. Chem. 3r, 44r.

Goldberg, D. M., Campbell, R. \& Roy, A. D. (1969). Scand. 7. Gastroenterol. 4, 217.

Harris, L. W. \& Phillipson, A. T. (1962). Anim. Prod. 4, 97.

Harrison, F. A. \& Leat, W. M. F. (1972). F. Physiol., Lond. 225, 565. 
Karvinen, E., Lin, T. M. \& Ivy, A. C. (r957a). Am. F. Physiol. r88, 6r.

Karvinen, E., Lin, T. M. \& Ivy, A. C. (I957b). Am. F. Physiol. r89, II3.

Khayat, M. H. \& Christophe, J. (1969). Am. Y. Physiol. 217, 923.

Leat, W. M. F. \& Harrison, F. A. (I969). Q. fl exp. Physiol. 54, 187.

Pekas, J. C., Hays, V. W. \& Thompson, A. M. (I964). F. Nutr. 82, 277.

Raven, A. M. (1970). F. Sci. Fd Agric. 21, 352.

Raven, A. M. \& Robinson, K. L. $(1964 a)$. F. Soc. Dairy Technol. 17, 5 .

Raven, A. M. \& Robinson, K. L. (1964b). F. Sci. Fd Agric. 15, 2 I4.

Roy, J. H. B. ( (967). Sb. vys. Šk. zemĕd. Brne 36, 325.

Roy, J. H. B. (1970). F. Sci. Fd Agric. 21, 346.

Roy, J. H. B., Shillam, K. W. G., Thompson, S. Y. \& Dawson, D. A. (I961). Br. J. Nutr. I5, 541.

Roy, J. H. B., Stobo, I. J. F. \& Gaston, H. J. (1968). Rep. natn. Inst. Res. Dairy. p. 66.

Roy, J. H. B., Stobo, I. J. F. \& Gaston, H. J. (r970). Br. F. Nutr. 24, 459.

Roy, J. H. B., Stobo, I. J. F., Gaston, H. J. \& Greatorex, J. C. (I970). Br. Y. Nutr. 24, 44I.

Roy, J. H. B., Stobo, I. J. F., Gaston, H. J., Shotton, S. M. \& Ganderton, P. (1973). Anim. Prod. I7, I09.

Shillam, K. W. G. \& Roy, J. H. B. (1963). Br. F. Nutr. 17, 17 I.

Siewert, K. L. \& Otterby, D. E. (I968). F. Dairy Sci. 5I, I305.

Taylor, R. B. (1962). Res. vet. Sci. 3,63.

Ternouth, J. H. \& Buttle, H. L. (I 973). Br. F. Nutr. 29, 387.

Ternouth, J. H., Roy, J. H. B. \& Siddons, R. C. (1974). Br. F. Nutr. 31, г3.

Toullec, R. (1967). Les Aliments D'Alliatement pour Veaux p. 59. Paris: National Renderers Association.

Toullec, R. \& Mathieu, C. M. (I969). Annls Biol. anim. Biochim. Biophys. 9, I 39.

Ugolev, A. M. (1965). Physiol. Rev. 45, 555.

Yates, F. (1933). Emp. F. exp. Agric, 1, 129. 